Original research article

\title{
Ethyl acetate extract of Clausena excavata induces growth inhibition of non-small-lung cancer, NCI-H460, cell line via apoptosis
}

\author{
Shaymaa Fadhel Abbas Albaayit ${ }^{1 *}$, Mariam Ashfaq Khan ${ }^{2}$, Rasedee Abdullah ${ }^{3}$, \\ Mohd Hezmee Mohd Noor ${ }^{4}$ \\ ${ }^{1}$ University of Baghdad, College of Science, Department of Biology, Baghdad, Iraq \\ ${ }^{2}$ University of Karachi, International Center for Chemical and Biological Sciences, Dr. Panjwani center for Molecular Medicine and Drug Research, \\ Karachi, Pakistan \\ ${ }^{3}$ Universiti Putra Malaysia, Faculty of Veterinary Medicine, Department of Veterinary Laboratory Diagnosis, Selangor, Malaysia \\ ${ }^{4}$ Universiti Putra Malaysia, Faculty of Veterinary Medicine, Department of Veterinary Preclinical Sciences, Selangor, Malaysia
}

\begin{abstract}
Context: Clausena excavata Burm. $\mathrm{f}$ is a plant used in folklore medicine for the treatment of various ailments in South East Asia. The plant parts contain chemical components that are cytotoxic to many cancer cells.

Objective: The study investigated the cytotoxic effects of ethyl acetate, methanol and chloroform $C$. excavata leaf extracts on the nonsmall-lung cancer, NCI-H460, cell line.

Methods: Based on the 3-(4,5-dimethylthiazol-2-yl)-2,5,-diphenyltetrazolium bromide (MTT) assay, among extracts, ethyl acetate C. excavata leaf extract (EACE) was the most potent anti-NCI-H460 cells, with $\mathrm{IC}_{50}$ value of $47.1 \pm 6.1 \mu \mathrm{g} / \mathrm{ml}$. The effects of EACE on NCI-H460 cells were also determined by clonogenic, 4', 6-diamidino-2-phenylindole (DAPI), and annexin-V-fluorescein isothiocyanate/ propidium iodide-PI flow cytometric assays. Reactive oxygen species (ROS) production and apoptotic gene expressions was determined via flow cytometry and real-time quantitative PCR, respectively.

Results: EACE-treated NCI-H460 cells after $48 \mathrm{~h}$ underwent apoptosis as evident by loss of cell viability, cell shrinkage, and chromatin condensation. The results also showed EACE mediated increase in ROS production by the NCI-H460 cells. After 48 h treatment, EACE increased the pro-apoptotic BAX and decreased the anti-apoptotic Bcl-2, Survivin and c-Myc gene expressions.

Conclusions: EACE is a potential anti-lung cancer by increasing cancer cell ROS production and apoptosis.
\end{abstract}

Keywords: Apoptosis; Cytotoxicity; ROS; Survivin

Highlights:

- Our study evaluated the mechanism of action of ethyl acetate extract on the non-small lung cancer, NCI-H460, cell line.

- Ethyl acetate $C$. excavata leaf extract inhibits lung cancer proliferation by increasing production of ROS and activation of apoptosis.

- Ethyl acetate $C$. excavata leaf extract is a potent anticancer agent.

Abbreviations: ATCC - American Type Culture Collection; Bax - Bcl 2 associated X protein; BCL2 - B cell lymphoma-2; CH - Chloroform; DAPI - 4, 6-diamidino-2-phenylindole; DCFH-DA - dichlorofluorescein; DMSO - dimethyl sulfoxide; EA - ethyl acetate; EACE - ethyl acetate extract of Clausena excavata; ELISA - enzyme-linked immunosorbent assay; FITC - fluorescein isothiocyanate; GAPDH - Glyceraldehyde-3-phosphate dehydrogenase; ICCBS - International Center for Chemical and Biological Sciences; MOH - Methanol; MTT - dimethylthiazol-2-yl)-2, 5,-diphenyltetrazolium bromide; NCI-H460 - Non-small-lung cancer cell lins; PCMD - Dr. Panjwani Center for Molecular Medicine \& Drug Research; PI - propidium iodide; PT - Petroleum ether; ROS - Reactive oxygen species; RPMI - Roswell Park Memorial Institute

\section{Introduction}

Cancer, one of the major causes of death, is on the increase in the last few decades. Lung cancers are among the most prevalent worldwide accounting for 31 to 57 cases of every 100,000 individuals (World Cancer Research Fund, 2019). Among lung cancers, non-small-lung cell cancer (NSCLC) accounts for approximately $85 \%$ of all cases. NSCLC is associated with smoking (Townsend et al., 2017). Like all cancers, the treatment of advanced NSCLC with surgery and chemotherapeutic drugs often failed because of drug resistance and cytotoxicity. There-

\footnotetext{
* Corresponding author: Shaymaa Fadhel Abbas Albaayit, University of Baghdad, College of Science, Department of Biology, Baghdad, Iraq; e-mail: shaymaa_albaayit@yahoo.com http://doi.org/10.32725/jab.2021.007

Submitted: 2020-04-04 • Accepted: 2020-12-09 • Prepublished online: 2021-03-01

J Appl Biomed 19/1: 40-47 • EISSN 1214-0287 • ISSN 1214-021X

(c) 2020 The Authors. Published by University of South Bohemia in České Budějovice, Faculty of Health and Social Sciences.

This is an open access article under the CC BY-NC-ND license.
} 
fore, it is necessary to discover safer and more efficacious anticancer therapeutic agents (Albaayit, 2020; Ling et al., 2016).

Plants are among the most common sources of drugs. Recently, research to determine the potential of plant-derived compounds for the cancer treatment had flourished with the discovery of many new drug candidates (Albaayit and Ozaslan, 2019; Greenwell and Rahman, 2015). The anticancer effects of these natural products are attributed to several mechanisms including apoptosis and necrosis (Albaayit et al., 2020a; Ullah et al., 2014).

Clausena excavata Burm. f. (Family: Rutaceae) is one of the species widely distributed in Southeast Asia that has been used in traditional medicine in Thailand for the treatment of cancers (Perry and Metzger, 1980; Waziri et al., 2016). This plant parts are also used to treat numerous disorders such as wounds, stomachaches fevers, abdominal pains, and cancers.

In Malaysia it's locally known as "Kemantu hitam", "Chemama" and "Cherek hitam". The plant contains many potent compounds shown to have immune-modulatory, anti-inflammatory, and anti-tumor, and wound healing properties (Albaayit et al., 2014; 2016; 2020c; Huang et al., 2017; Waziri et al., 2016).

C. excavata parts have been shown to be rich in polyphenol compounds such as alkaloids, flavonoid carbazole glycosides, and coumarins. The coumarins are among the main components of the C. excavata extracts reported to exhibit anticancer, antibacterial, and antimalarial effects. Among the coumarins, furanocoumarins are antiproliferative towards cancer cells (Albaayit, 2021; Bruni et al., 2019). Other components of C. excavata extracts, including nordentatin, xanthoxyletin, clausarin, and dentatin $C$ are cytotoxic to hepatoma, prostate cancer, and human promyelocytic leukemia cell lines (Huang et al., 2017). Currently, there is no scientific evidence suggesting that this plant is therapeutically efficacious towards lung cancers. Thus, we investigated the in vitro effect of $C$. excavata leaf extracts on the non-small-lung cancer, NCI-H460, cell line.

\section{Materials and methods}

\section{Preparation of plant material}

The leaves of $C$. excavata plant obtained from Pendang, Kedah, Malaysia ( $5^{\circ} 59^{\prime} \mathrm{N}, 100^{\circ} 28^{\prime} \mathrm{E}$ ) on December 2010 and were identified by Dr. Shamsul Khamis (Resident Botanist) at the Biodiversity Unit, Institute of Bioscience, Universiti Putra Malaysia, voucher specimen (TI-013201-CE). Fresh leaves were dried at room temperature, powdered and extracted according to the method described in our previous study (Albaayit et al., 2014). A mixture comprised of $1: 5$ ratio of dried plant by weight to petroleum ether (PT) by volume was subject to the extraction. The filtrate was collected and the residues subjected to further extraction with chloroform $(\mathrm{CH})$, ethyl acetate (EA), and methanol (MOH). The filtrates were again collected and evaporated in a rotary evaporator under reduced pressure at $45-50{ }^{\circ} \mathrm{C}$ to obtain stock crude extract. Only the methanol and ethyl acetate $C$. excavata extracts were sent for LCMS/MS analysis to screen for the presence of phytochemicals (Advance Chemistry Solution, GHOD Sdn Bhd ACD/Labs Inc., Malaysia). The stock extracts were dissolved in $0.1 \%$ dimethyl sulfoxide (DMSO) to obtain the respective extract concentrations used in the study.

\section{Cell maintenance and 3-(4,5-dimethylthiazol-2-yl)-2,} 5,-diphenyltetrazolium bromide (MTT) assay

The human non-small-lung cancer, NCI-H460, cell line, a tumor of NSCLC subtype, was obtained from cell culture bio bank (PCMD, ICCBS) from American Type Culture Collection (ATCC), was cultured and passaged using RPMI medium (Albaayit et al., 2019; Zehra et al., 2019). The cytotoxic effect of the solvent extracts on the NCI-H460 cell lines was investigated using the MTT assay (Sajid et al., 2018). $5 \times 10^{3}$ NCI-H460 cells/well were placed in each well in a 96-well plate and incubated for $24 \mathrm{~h}$ at $37^{\circ} \mathrm{C}$, before treatment with $12.5-100 \mu \mathrm{g} / \mathrm{ml}$ of the $\mathrm{MOH}, \mathrm{EA}, \mathrm{CH}$, and PT fractions, while the control was treated with $0.1 \%$ DMSO for 48 h. $20 \mu$ of MTT $(5 \mathrm{mg} / \mathrm{ml})$ reagent was added to each well and the plate incubated for $4 \mathrm{~h}$ at $37^{\circ} \mathrm{C}$. The purple formazan crystals formed were dissolved with $150 \mu \mathrm{l}$ DMSO and the absorbance measured at $570 \mathrm{~nm}$ using an ELISA plate reader (Tecan, California, USA). The cancer cell growth inhibition was expressed as $\mathrm{IC}_{50}$ (half-maximal inhibitory concentration) value.

\section{Colony formation assay}

The NCI-H460 cells were seeded at a density of $1 \times 10^{4}$ cells/ well $/ 1 \mathrm{ml}$ in a 6 -well plate overnight to confluence, treated with $47\left(\mathrm{IC}_{50}\right)$ and $100 \mu \mathrm{g} / \mathrm{ml} \mathrm{EACE}$, and the plate incubated for 21 days at $37^{\circ} \mathrm{C}$. At the end of the incubation period, $2 \mathrm{ml}$ $0.5 \%$ (w/v) of crystal violet in $25 \%$ ethanol was then added to each well and the plate incubated for another $30 \mathrm{~min}$ at room temperature. After removal of excess stain, the cells washed with $\mathrm{ddH}_{2} \mathrm{O}$ and the colonies formed immediately photographed and counted (Sajid et al., 2018).

\section{Apoptosis}

Annexin-V/propidium iodide assay (PI)

The early and late apoptosis in NCI-H460 cells were determined using the PI staining technique (Thermo Fisher Scientific). Briefly, $1 \mathrm{ml}$ of $1 \times 10^{6} \mathrm{NCI}-\mathrm{H} 460$ cells suspension was seeded into each well of a 6 -well plate and the plate was incubated for $24 \mathrm{~h}$ at $37^{\circ} \mathrm{C}$, treated with EACE at concentration either 47 or $100 \mu \mathrm{g} / \mathrm{ml}$ to the respective wells and the plate incubated for $48 \mathrm{~h}$. After the treatments, the cells were harvested by trypsinization, washed thrice with phosphate buffered saline (PBS), and stained with $5 \mu$ l fluorescein isothiocyanate (FITC)-conjugated annexin-V and $5 \mu \mathrm{l}$ PI for $15 \mathrm{~min}$ at room temperature in the dark. The percentage of cells in apoptosis and necrosis were determined by flow cytometry on FACSCalibur ${ }^{\mathrm{TM}}$ (Becton Dickinson).

\section{4,6-diamidino-2-phenylindole assay (DAPI)}

DAPI staining is one of the most commonly used fluorescent-based assays for the determination of the effect of treatments on cell morphology (Rahman and Hussain, 2015). The NCI-H460 cells were seeded into each well at a density of $1 \times 10^{6} \mathrm{NCI}-\mathrm{H} 460$ cells/well/ml in a 6-well plate for $24 \mathrm{~h}$ at $37{ }^{\circ} \mathrm{C}$, treated with either 47 or $100 \mu \mathrm{g} / \mathrm{ml}$ EACE in Roswell Park Memorial Institute Medium, and the plate incubated for $48 \mathrm{~h}$ at $37^{\circ} \mathrm{C} .100 \mu \mathrm{l}$ of DAPI $(1: 1000)$ was added to each well and the plate incubated for $1 \mathrm{~h}$ at room temperature. The cells were observed for fluorescence, fragmentation, and nuclear condensation under Nikon fluorescence microscopy at 200x magnification.

\section{Reactive oxygen species (ROS)}

Flow cytometry was used to determine production of ROS by treated NCI-H460 cells (Ahamed et al., 2013). $500 \mu \mathrm{l}$ of $1 \times 10^{6}$ NCI-H460 cells were seeded into each well of 24-well plate and treated with either 47 or $100 \mu \mathrm{g} / \mathrm{ml}$ EACE and the plate incubated for $48 \mathrm{~h}$. Non treated cells served as negative while cells treated $50 \mu \mathrm{l}(50 \mu \mathrm{M})$ hydrogen peroxide $\left(\mathrm{H}_{2} \mathrm{O}_{2}\right)$ were the positive control. The cells were then detached by trypsin- 
ization, washed twice with phosphate buffered saline (PBS), and re-suspended with $500 \mu 10 \mu \mathrm{M}$ 2, 7-dichlorofluorescein DCFH-DA for 30 min at $37^{\circ} \mathrm{C}$ in the dark. ROS generation was determined via flow cytometry (FACSCalibur ${ }^{\mathrm{TM}}$ Cell Quest Pro Software version 2.0).

\section{Quantitative Real-time polymerase chain reaction (RT-qPCR)}

RT-qPCR was used to determined expression of apoptosis-related genes in treated NCI-H460 cells. The NCI-H460 cell were seeded into each well of a 6-well plate at a density of $1 \times 10^{6}$ NCI-H460 cell/well/ml and treated $47 \mu \mathrm{g} / \mathrm{ml}$ EACE for $48 \mathrm{~h}$.
Total RNA was isolated from harvested cells using the TRIzol ${ }^{\circledR}$ Reagent (Bio basic BS410A, Canada). Complementary DNA (cDNA) was synthesized from $1 \mu \mathrm{g}$ of total RNA using cDNA synthesis kit (Thermo Fisher Scientific K0221). Then, $1 \mu \mathrm{l}$ of cDNA was amplified by real-time PCR using primers listed in Table 1 . The amplification of genes was performed using SYBR Green Master Mix (Thermo Fisher Scientific). LightCycler ${ }^{\circledR}$ 480 Gene Scanning Software (Agilent Technologies Stratagene Mx 3000P, Santa Clara, CA) was used to generate the results and calculate number of transcripts relative to the normal control. GAPDH was used as the housekeeping gene control (Albaayit et al., 2020b, c; Hidayat et al., 2016).

Table 1. Genes and primer sequences

\begin{tabular}{llc}
\hline Gene & Forward primer sequence & Reverse primer sequence \\
\hline BCL2-associated X (BAX) & AAGAAGCTGAGCGATGTC & GGCCCCAGTTGAAGTTGC \\
B cell lymphoma-2 (BCL2) & GGCATTCAGTGACCTGACATC & AGTCATGCCCGTCAGGAAC \\
Survivin & CAGAGTCCCTGGCTCCTCTAC & GGCTCACTGGGCCTGTCTA \\
C-Myc & CACAGCAAACCTCCTCACAG & GGTGCATTTTCGGTTGTTGC \\
Glyceraldehyde-3-phosphate dehydrogenase (GAPDH) & CCAGAACATCATCCCTGCCT & CCAGAACATCATCCCTGCCT \\
\hline
\end{tabular}

\section{Statistical analysis}

Data are expressed as mean \pm SD and level of significance at $P<0.05$ determined by one-way analysis of variance using SPSS (Version 19.0; IBM Corporation, Armonk, NY, USA). All experiments were performed in triplicates.

\section{Results}

The yield (wt. of crude extract / wt. of fresh plant) of the petroleum ether, chloroform, ethyl acetate, and methanol extracts of $C$. excavata leaf were of $1.56,2.57,0.38$, and $0.94 \%$, respectively.

\section{LCMS/MS screening}

EACE has high contents of phenolic acid, furocoumarin-based compounds, and 8-geranyloxy psoralen and its isomer (Fig. 1 on the next page).

\section{Cytotoxicity assay}

Among extracts, the ethyl acetate $C$. excavata extract (EACE) was most active against cancer cells, showing the lowest mean $\mathrm{IC}_{50}$ of $47 \mu \mathrm{g} / \mathrm{ml}$ (Table 2) against NCI-H460 cells, and hence was chosen for subsequent studies.

After 21 days of incubation, 47 and $100 \mu \mathrm{g} / \mathrm{ml}$ EACE inhibited NCI-H460 colony formation by 73 and $99 \%$, respectively, relative to the control (Fig. 2).

Table 2. $\mathrm{IC}_{50}$ values of Clausena excavata extracts treatment on NCI-H460 after $48 \mathrm{~h}$

\begin{tabular}{lc}
\hline Fraction & $\mathrm{IC}_{50}(\mu \mathrm{g} / \mathrm{ml})$ \\
\hline Petroleum ether & $>100$ \\
Chloroform & $55.16 \pm 9.10$ \\
Ethyl acetate & $47.10 \pm 6.10$ \\
Methanol & $>100$ \\
\hline
\end{tabular}

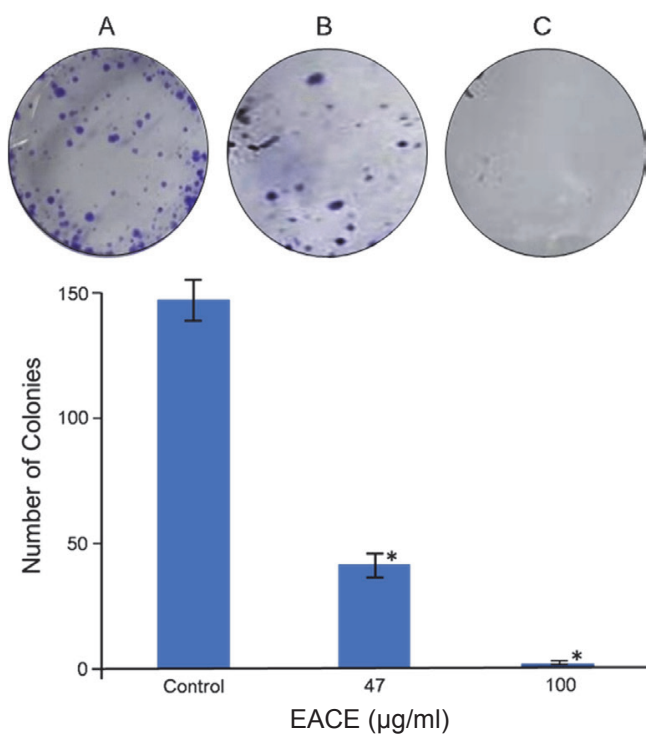

Fig. 2. Colony formation by the NCI-H460 cells treated with ethyl acetate $C$. excavata leaf extract (EACE). Treatment with EACE produced dose-dependent inhibition of colony formation. (A) Control, (B) $47 \mu \mathrm{g} / \mathrm{ml}$, and (C) $100 \mu \mathrm{g} / \mathrm{ml} \mathrm{EACE.} \mathrm{*} \mathrm{Means}$ significantly different control at $p<0.05$.

\section{NCI-H460 cell apoptosis}

Under DAPI staining, the EACE treated NCI-H460 cells showed morphological changes (Fig. 3). Treated cells underwent apoptosis as evident by cell shrinkage and condensed nucleus. On the contrary, the non-treated control cells were mostly intact. Upon treatment of NCI-H460 cells with EACE at $100 \mu \mathrm{g} / \mathrm{ml}$, late apoptosis phase increased up to $77.3 \%$, which was much higher as compared to $47 \mu \mathrm{g} / \mathrm{ml}$ which increased up to $24.5 \%$ (Fig. 4). 

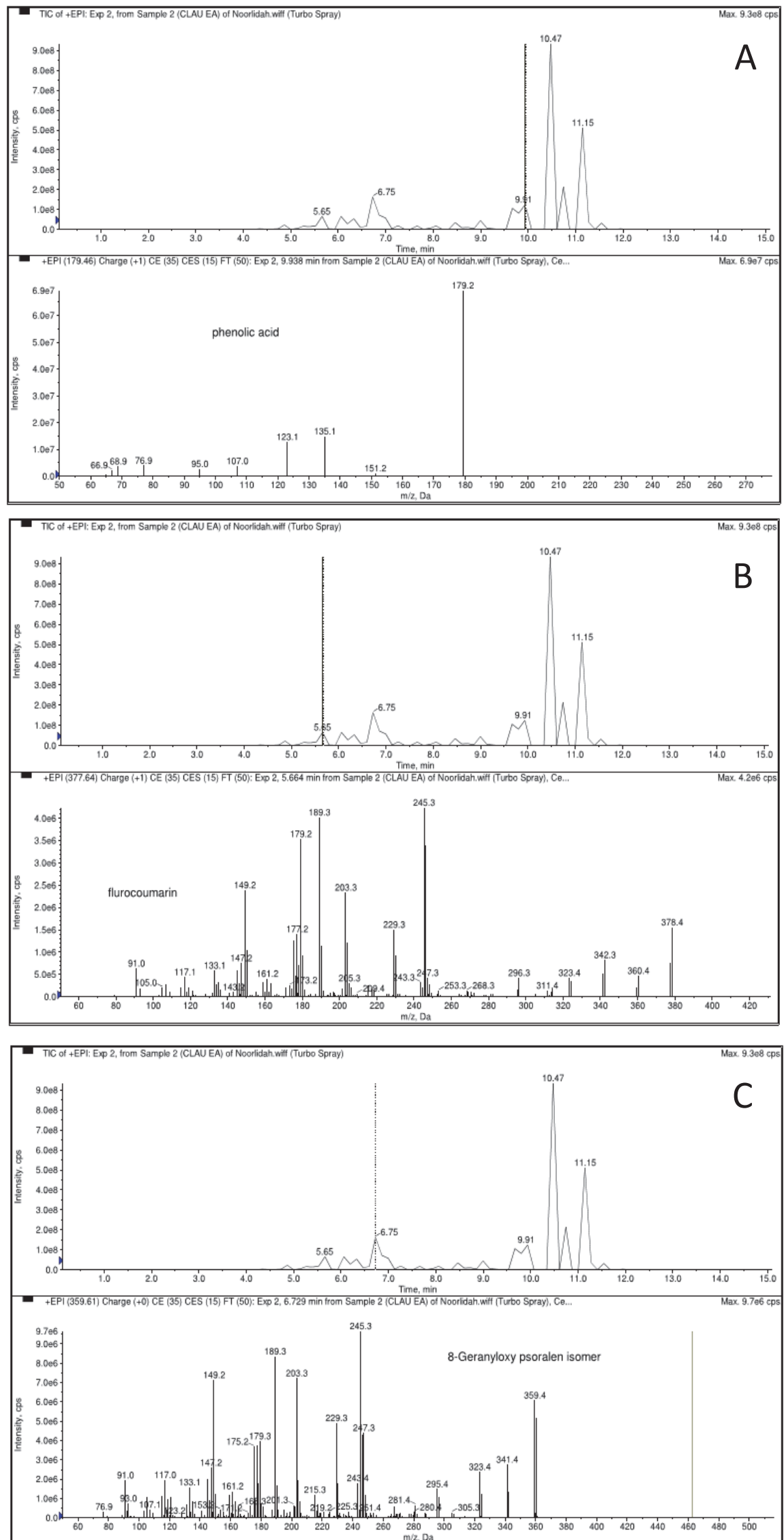

Fig. 1. LCMS/MS characterizations of ethyl acetate C. excavata leaf extract showing its high contents of (A) phenolic acid, (B) furocoumarin, and (C) 8-geranyloxy psoralen isomer. 
A

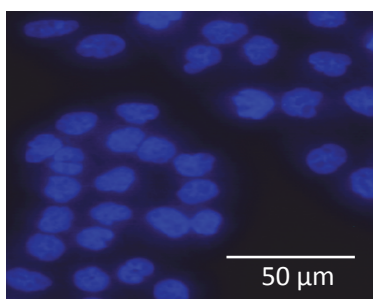

B

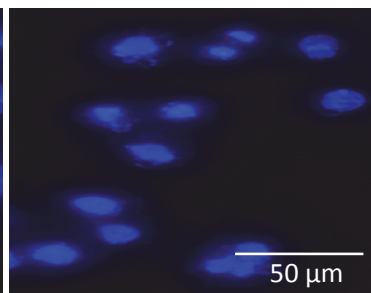

C

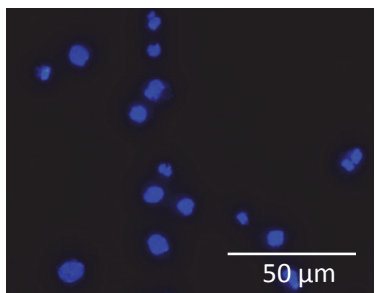

Fig. 3. Ethyl acetate C. excavata leaf extract (EACE)-treated non-small cell lung cancer, NCI-H460, cell line after 4, 6-diamidino-2-phenylindole (DAPI) staining. After treatment with (B) 47 and (C) $100 \mu \mathrm{g} / \mathrm{ml}$ of EACE, the cells show shrinkage and condensed chromatin. The effect was more prominent at the higher EACE treatment dose. (A) Control (Magnification 200x).
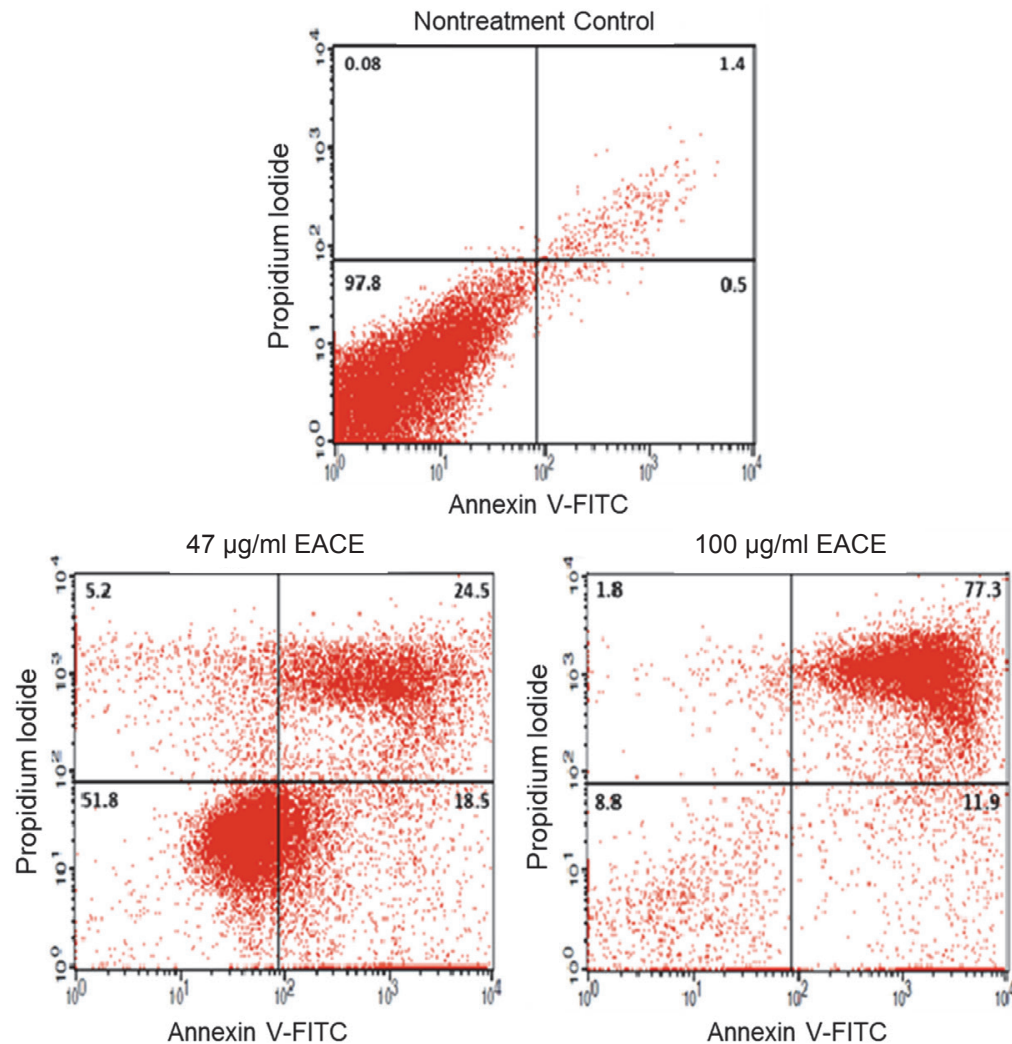

Fig. 4. Flow cytometric analysis of non-small cell lung cancer, NCI-H460, cell line. Cells treated with 47 and $100 \mu \mathrm{g} / \mathrm{ml}$ ethyl acetate $C$. excavata leaf extract (EACE) for $48 \mathrm{~h}$. Control show low number of apoptotic cells. Significantly high apoptotic cells treated EACE especially at the higher dose.

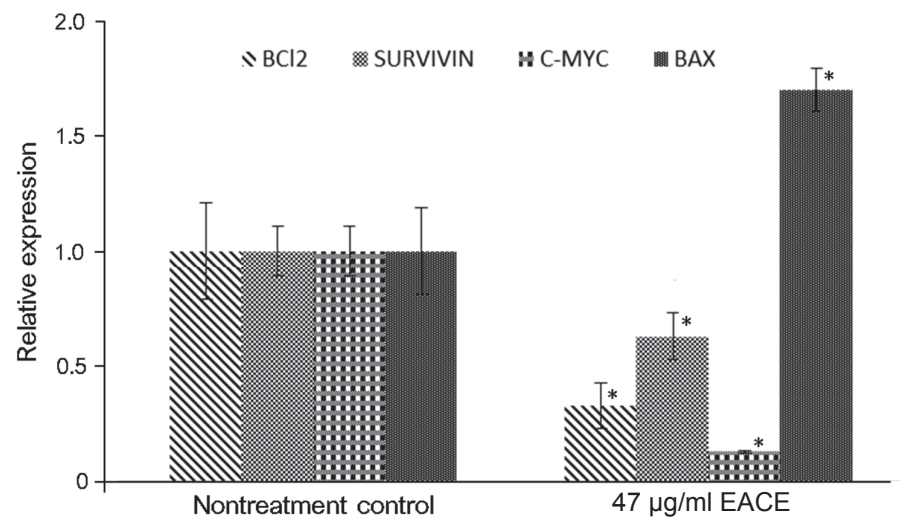

Fig. 5. mRNA expression of BAX, BCL2, survivin and c-Myc genes in non-small cell lung cancer, NCI-H460, cell line treated with $47 \mu \mathrm{g} / \mathrm{ml}\left(\mathrm{IC} \mathrm{C}_{50}\right)$ ethyl acetate $C$. excavata leaf extract (EACE). Values are mean \pm standard deviation. * Mean significantly different $(p<0.05)$ from the respective nontreatment control mean. 

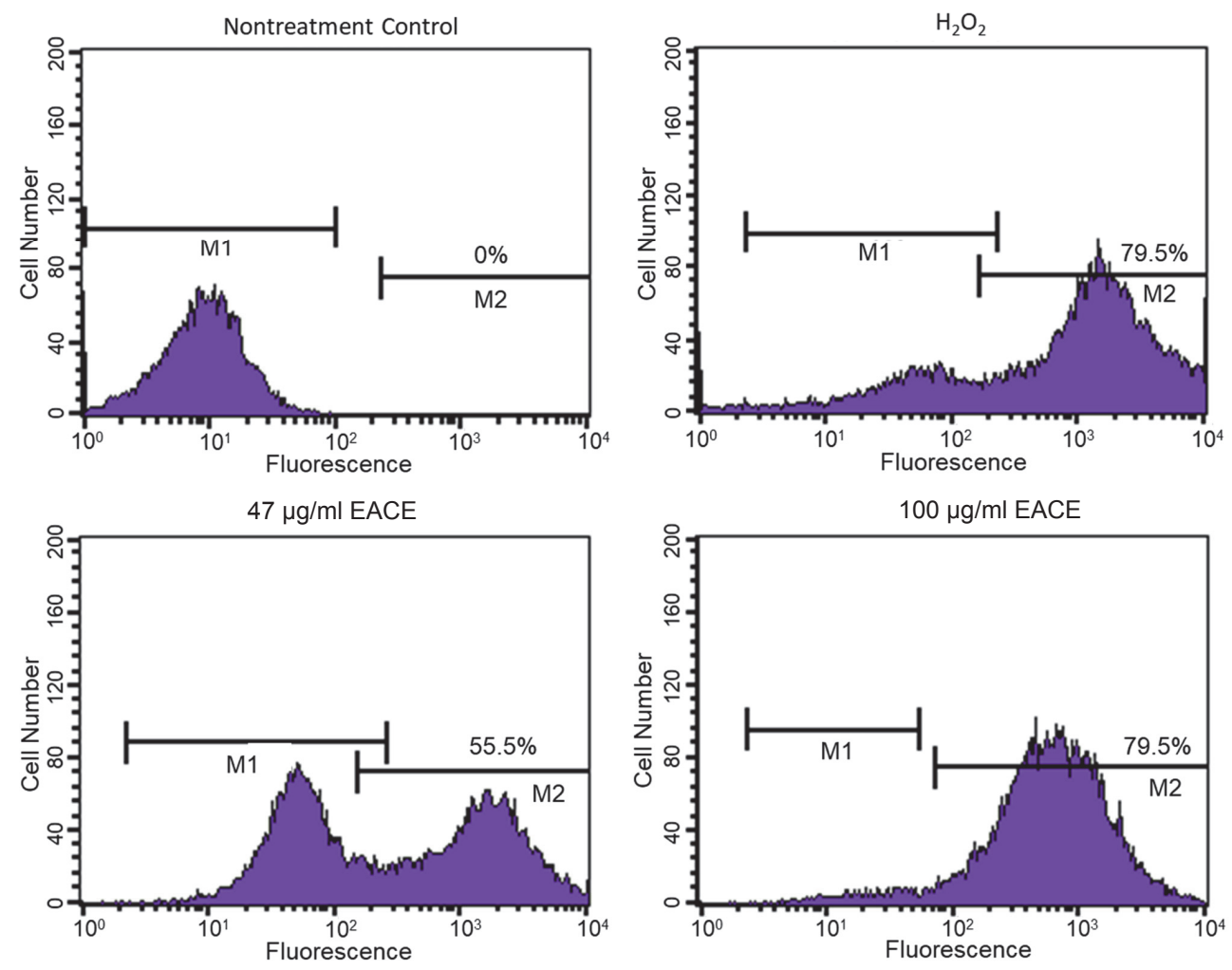

Fig. 6. ROS generation by NCI-H460 cells treated with C. excavata leaf extract (EACE). Increase in ROS level was dose-dependent, with higher production after treatment with 100 than with $47 \mu \mathrm{g} / \mathrm{ml}$ EACE. Hydrogen peroxide $\left(\mathrm{H}_{2} \mathrm{O}_{2}\right)$-treated cells were the positive control.

\section{Expression of apoptotic and anti-apoptotic genes in NCI-H460 cell}

After 48 h-treatment, the NCI-H460 expression of BAX gene was significantly $(p<0.05)$ up regulated by $\sim 1.7$-fold, while that of Bcl-2, surviving and c-MYC genes down-regulated by 3.1-, 1.6- and 5.7-fold, respectively, in comparison with the control (Fig. 5).

\section{Reactive oxygen species (ROS) production by NCI-H460 cells}

After treatment with 47 and $100 \mu \mathrm{g} / \mathrm{ml}$ EACE for $24 \mathrm{~h}$, ROS production by NCI-H460 cells increased significantly by 55.5 and $79.5 \%$, respectively. The positive $\left(\mathrm{H}_{2} \mathrm{O}_{2}\right)$ control cells showed significant increase in ROS production while the non-treated cells did not generate ROS (Fig. 6).

\section{Discussion}

Over the last decade the field of ethno-pharmacology had steadily gained the interest of researchers, especially those in search of novel natural compounds with potent anticancer properties (Zehra et al., 2019). Now, it is known that many medicinal plants possess anti-proliferative properties for various types of cancer. C. excavata is one of the plants with parts that contain several compounds with a wide array of biological activities, including anticancer, antitumor, antimalarial, anti-inflammatory, and antiviral properties (Huang et al., 2017; Waziri et al., 2016). We subjected the leaves of C. excavata to the extraction process using various solvents to determine the extract with potentially the best anticancer properties. Among these extracts, EACE exhibited the most potent anti-prolifer- ative effect towards the NCI-H460 cells. The leaves of $C$. excavata are especially high in phenolic contents that could be main contributor to the cancer cell apoptotic effect of the extract (Huang et al., 2017; Waziri et al., 2016). In the development of therapeutics, compounds that could specifically cause cancer cell apoptosis would be ideal candidates as anticancer drugs (Che et al., 2018; Huang et al., 2017). In this study, the apoptosis-inducing properties were investigated using the annexin $\mathrm{V} /$ propidium iodide staining of the EACE-treated NCI-H460 cells. It was shown that EACE induced significant NCI-H460 cell late apoptosis after $48 \mathrm{~h}$ treatment. The apoptotic effect of EACE was also evident by the condensed chromatin and loss of normal cellular morphology. The study also showed that EACE caused significant up-regulation of the pro-apoptotic BAX gene, while the anti-apoptotic survivin, Bcl-2, and c-Myc genes were down-regulated (Kim et al., 2014; Sivakumaran et al., 2018). Since increase in BAX expression and down-regulation of survivin, Bcl-2, and $\mathrm{cMyc}$ genes are mitochondria-mediated (Losuwannarak et al., 2018; Yao et al., 2017), it is suggested the at least the intrinsic apoptosis pathway is involved in the anti-proliferative effect of EACE on the NCI-H460 cells.

There are numerous evidences that showed ROS has both tumor-promoting (Reczek and Chandel, 2018) and tumor-suppression effects (Wang et al., 2017), presumably dependent on the concentration of ROS in the tumor microenvironment and state of tumor cells (de Sá et al., 2017). It was proposed that response of tumors to ROS follows a threshold concept, where the cancer cells enter an adaptive state to increasing ROS and eventually perish as the ROS level exceeds a certain limit (Redza-Dutordoir and Averill-Bates, 2016). Excessive ROS is toxic to cells and can cause apoptosis and necrosis (Albaayit and Maharjan, 2018; Al-Bahrani et al., 2020; Mileo and Miccadei, 2016). Our study showed that EACE induced increased 
ROS generation by the NCI-H460 cells to a level that exceeded the capacity of the cellular anti-oxidant defense mechanism, resulting in damage to the mitochondrial membrane and tumor cell death (Avendaño and Menendez., 2015; Hu et al., 2014). Evidently, the cancer cell killing effect of ROS occurs through both the intrinsic and extrinsic apoptosis pathways (Essafi Rhouma et al., 2019).

Phenols from plant, including C. excavata, have anticancer, antioxidant, and pro-oxidant properties (Essafi Rhouma et al., 2019). The EACE, in particular, has high phenolic content and it is proposed that these compounds are responsible for excessive ROS production resulting in the anti-proliferation of NCI-H460 cells (Albaayit et al., 2014). Phenols can cause cell arrest and premature aging, facilitating their anticancer effects (Mileo and Miccadei, 2016). It was suggested that phenolic compounds inhibit the stress-activated NF- $\kappa$ B and AP-1 signaling cascade. Phenolics also enhance the immune system in the destruction of cancer cells, inhibit angiogenesis, and reduce the metastatic potential of tumors (Mohammad and Mahdi, 2017). Based on the evidences in this study and those reported earlier, the EACE has potential to be developed into an anticancer agent.

\section{Conclusions}

In conclusion, the results collectively provided evidence that the EACE is toxic to the lung cancer, NCI-H460, cells and the anticancer effect of the extract is through the activation of apoptosis-induction with concomitant inhibition of the anti-apoptosis mechanisms. Therefore, the findings show that EACE is a promising and novel chemotherapeutic agent for the treatment of lung cancers.

\section{Conflict of interests}

We wish to confirm that there is no known conflict of interests associated with this publication and there has been no significant financial support for this work that could have influenced its outcome.

\section{Acknowledgements}

The authors wish to express utmost gratitude and appreciation to NAM- ICCBS (International Center for Chemical and Biological Sciences, University of Karachi, Karachi, Pakistan) and Prof. Dr. M. Iqbal Choudhary (Director, ICCBS) for fellowship Award to Shaymaa Fadhel Abaas Albaayit.

\section{Author contributions}

SFAA and MAK conceptualized, designed and conducted the experiment. SFAA, RA and MMNH interpreted the data and wrote the manuscript draft. All authors have read and approved the final manuscript.

\section{References}

Ahamed M, Ali D, Alhadlaq HA, Akhtar MJ (2013). Nickel oxide nanoparticles exert cytotoxicity via oxidative stress and induce apoptotic response in human liver cells (HepG2). Chemosphere 93(10): 2514-2522. DOI: 10.1016/j.chemosphere.2013.09.047.

Albaayit SFA (2020). In Vitro Evaluation of Anticancer Activity of Moringa Peregrina Seeds on Breast Cancer Cells. The Eurasia Proceedings of Science Technology Engineering and Mathematics 11: 163-166.
Albaayit SFA (2021). Evaluation of anti-methicillin resistant Staphylococcus aureus property of Clausena excavata leaves by using atomic force microscopy and flowcytometry techniques. Pak J Agri Sci 58(1): 315-320. DOI: 10.21162/PAKJAS/21.921.

Albaayit SFA, Maharjan R (2018). Immunomodulation of Zerumbone via Decreasing the Production of Reactive Oxygen Species from Immune Cells. Pak J Biol Sci 21(9): 475-479. DOI: 10.3923/pjbs.2018.475.479.

Albaayit SFA, Ozaslan M (2019). Cytotoxic and urease inhibition potential of Moringa peregrina Seed Ethanolic Extract. Int J Pharmacol 15(1): 151-155. DOI: 10.3923/ijp.2019.151.155.

Albaayit SFA, Abba Y, Abdullah R, Abdullah N (2014). Evaluation of antioxidant activity and acute toxicity of Clausena excavata leaves extract. Evid Based Complement Alternat Med 2014: 975450. DOI: 10.1155/2014/975450.

Albaayit SFA, Abba Y, Abdullah R, Abdullah N (2016). Prophylactic effects of Clausena excavata Burum. f. leaf extract in ethanolinduced gastric ulcers. Drug Des Devel Ther 10: 1973-1986. DOI: 10.2147/DDDT.S103993.

Albaayit SFA, Al-Khafaji ASK, Alnaimy HS (2019). In vitro macrophage nitric oxide and interleukin- 1 beta suppression by Moringa peregrine seed. Turk J Pharm Sci 16(3): 362-365. DOI: 10.4274/tjps.galenos.2018.52244.

Albaayit SFA, Maharjan R, Khan M (2020a). Evaluation of Hemolysis Activity of Zerumbone on RBCs and Brine Shrimp Toxicity. Baghdad Sci J 18(1): 0065. [online] [cit. 2020-12-09]. Available from: http://bsj.uobaghdad.edu.iq/index.php/BSJ/article/ view/5434

Albaayit SFA, Rasedee A, Abdullah N (2020b). Zerumbone-loaded nanostructured lipid carrier gel facilitates wound healing in rats. Rev Bras Farmacogn 30: 272-278. DOI: 10.1007/s43450-02000023-7.

Albaayit SFA, Rasedee A, Abdullah N, Abba Y (2020c). Methanolic extract of Clausena excavata promotes wound healing via antiinflammatory and anti-apoptotic activities. Asian Pac J Trop Biomed 10(5): 232-238. DOI: 10.4103/2221-1691.281467.

Al-Bahrani RM, Radif HM, Albaayit SFA (2020). Evaluation of potent silver nanoparticles production from Agaricus bisporus against Helicobacter pylori. Pak J Agri Sci 57(4): 1197-1201. DOI: 10.21162/PAKJAS/20.9893.

Avendaño C, Menendez JC (2015). Medicinal chemistry of anticancer drugs. 2nd ed. Hungary: Elsevier, pp. 95-100.

Bruni R, Barreca D, Protti M, Brighenti V, Righetti L, Anceschi L, et al. (2019). Botanical sources, chemistry, analysis, and biological activity of furanocoumarins of pharmaceutical interest. Molecules 24(11): 2163. DOI: 10.3390/molecules24112163.

Che Y, Li J, Li Z, Li J, Wang S, Yan Y, et al. (2018). Osthole enhances antitumor activity and irradiation sensitivity of cervical cancer cells by suppressing ATM/NF- $\mathrm{BB}$ signaling. Oncol Rep 40(2): 737-747. DOI: 10.3892/or.2018.6514.

de Sá PL, Jr., Câmara DAD, Porcacchia AS, Fonseca PMM, Jorge SD, Araldi RP, Ferreira AK (2017). The Roles of ROS in Cancer Heterogeneity and Therapy. Oxid Med Cell Longev 2017: 2467940. DOI: $10.1155 / 2017 / 2467940$

Essafi Rhouma H, Trabelsi N, Chimento A, Benincasa C, Tamaalli A, Perri E, et al. (2019). Olea europaea L. flowers as a new promising anticancer natural products: phenolic composition, antiproliferative activity and apoptosis induction. Nat Prod Res 8: 1-4. DOI: 10.1080/14786419.2019.1637867.

Greenwell M, Rahman PKSM (2015). Medicinal plants: Their use in anticancer treatment. Int J Pharm Sci Res 6(10): 4103-4112. DOI: 10.13040/IJPSR.0975-8232.6(10).4103-12.

Hidayat M, Prahastuti S, Fauziah N, Maesaroh M, Balqis B, Widowati W (2016). Modulation of Adipogenesis-related Gene Expression by Ethanol Extracts of Detam 1 Soybean and Jati belanda Leaf in 3T3-L1 Cells. Bangladesh J Pharmacol 11(3): 697-702. DOI: 10.3329/bjp.v11i3.26471.

Hu Z, Zeng Q, Zhang B, Liu H, Wang W (2014). Promotion of p53 expression and reactive oxidative stress production is involved in zerumbone-induced cisplatin sensitization of non-small cell lung cancer cells. Biochimie 107 Pt B: 257-262. DOI: 10.1016/j. biochi.2014.09.001. 
Huang L, Feng ZL, Wang YT, Lin LG (2017). Anticancer carbazole alkaloids and coumarins from Clausena plants: A review. Chin J Nat Med 15(12): 881-888. DOI: 10.1016/S18755364(18)30003-7.

Kim KH, Choi I, Lee YW, Cho CK, Yoo HS, Lee SB, et al. (2014). Target genes involved in antiproliferative effect of modified ginseng extracts in lung cancer A549 cells. Acta Biochim Biophys Sin (Shanghai) 46(6): 441-449. DOI: 10.1093/abbs/gmu025.

Ling B, Michel D, Sakharkar MK, Yang J (2016). Evaluating the cytotoxic effects of the water extracts of four anticancer herbs against human malignant melanoma cells. Drug Des Devel Ther 10: 3563-3572. DOI: 10.2147/dddt.s119214.

Losuwannarak N, Sritularak B, Chanvorachote P (2018). Cycloartobiloxanthone Induces Human Lung Cancer Cell Apoptosis via Mitochondria-dependent Apoptotic Pathway. In Vivo 32(1): 71-78. DOI: 10.21873/invivo.11206.

Mileo AM, Miccadei S (2016). Polyphenols as modulator of oxidative stress in cancer disease: New therapeutic strategies. Oxid Med Cell Longev 2016: 6475624. DOI: 10.1155/2016/6475624.

Mohammad AJ, Mahdi NR (2017). Effect of grape seed polyphenol on immune gene expression and its role as antibacterial against Salmonella typhimurium infection in mice exposed to sodium nitrate. Int J Adv Res Biol Sci 4(7): 27-37. DOI: 10.22192/ijarbs.

Perry LM, Metzger J (1980). Medicinal plants of East and Southeast Asia: attributed properties and uses. MIT press.

Rahman MA, Hussain A (2015). Anticancer activity and apoptosis inducing effect of methanolic extract of Cordia dichotoma against human cancer cell line. Bangladesh J Pharmacol 10(1): 27-34. DOI: 10.3329/bjp.v10i1.20883.

Reczek CR, Chandel NS (2018). ROS promotes cancer cell survival through calcium signaling. Cancer Cell 33(6): 949-951. DOI: 10.1016/j.ccell.2018.05.010.

Redza-Dutordoir M, Averill-Bates DA (2016). Activation of apoptosis signalling pathways by reactive oxygen species. Biochem Biophys Acta 1863(12): 2977-2992. DOI: 10.1016/j.bbamcr.2016.09.012.

Sajid A, Manzoor Q, Iqbal M, Tyagi AK, Sarfraz RA, Sajid A (2018). Pinus Roxburghii essential oil anticancer activity and chemical composition evaluation. EXCLI J 17: 233-245. DOI: 10.17179/ excli2016-670.
Sivakumaran N, Samarakoon SR, Adhikari A, Ediriweera MK, Tennekoon KH, Malavige N, et al. (2018). Cytotoxic and Apoptotic Effects of Govaniadine Isolated from Corydalis govaniana Wall. Roots on Human Breast Cancer (MCF-7) Cells. Biomed Res Int 2018: 3171348. DOI: $10.1155 / 2018 / 3171348$.

Townsend MH, Anderson MD, Weagel EG, Velazquez EJ, Weber KS, Robison RA, O’Neill KL (2017). Non-small-cell lung cancer cell lines A549 and NCI-H460 express hypoxanthine guanine phosphoribosyltransferase on the plasma membrane. Onco Targets Ther 10: 1921-32. DOI: 10.2147/OTT.S128416.

Ullah MF, Bhat SH, Husain E, Abu-Duhier F, Hadi SM, Sarkar FH, Ahmad A (2014). Cancer chemopreventive pharmacology of phytochemicals derived from plants of dietary and non-dietary origin: implication for alternative and complementary approaches. Phytochem Rev 13: 811-833. DOI: 10.1007/s11101-014-9341-9.

Wang J, Luo B, Li X, Lu W, Yang J, Hu Y, et al. (2017). Inhibition of cancer growth in vitro and in vivo by a novel ROS-modulating agent with ability to eliminate stem-like cancer cells. Cell Death Dis 8: e2887. DOI: 10.1038/cddis.2017.272.

Waziri PM, Abdullah R, Yeap SK, Omar AR, Abdul AB, Kassim NK, et al. (2016). Clausenidin from Clausena excavata induces apoptosis in hepG2 cells via the mitochondrial pathway. J Ethnopharmacol 194: 549-558. DOI: 10.1016/j.jep.2016.10.030.

World Cancer Research Fund, American Institute of Cancer Research (2019). Lung cancer statistics. [online] [cit. 2019-07-14]. Available from: https://www.wcrf.org/dietandcancer/cancer-trends/lungcancer-statistics

Yao C, Cao X, Fu Z, Tian J, Dong W, Xu J, et al. (2017). Boschniakia Rossica polysaccharide triggers laryngeal carcinoma cell apoptosis by regulating expression of Bcl-2, Caspase-3, and P53. Med Sci Monit 23: 2059-2064. DOI: 10.12659/MSM.901381.

Zehra B, Ahmed A, Sarwar R, Khan A, Farooq U, Abid Ali S, Al-Harrasi A (2019). Apoptotic and antimetastatic activities of betulin isolated from Quercus incana against non-small cell lung cancer cells. Cancer Manag Res 11: 1667-1683. DOI: 10.2147/ CMAR.S186956. 